\title{
Peran Perilaku Etis Tenaga Penjual dalam Membentuk Kualitas Hubungan dan Loyalitas Pelanggan \\ Nunung Ghoniyah*
}

\begin{abstract}
This article explains about the important of ethical behavior of sales person to create customer loyalty trough relationship quality. It is very important especially for service business in order to the quality of service is not easy to measured. To evaluate quality service, consumer can see the tangible signals and interaction quality of front line employees. Unethical behavior of sales person such as unhonest, force and unknow about product knowledge cause low relationship quality (commitment and trust). Finally, relationship quality cause the customer willing or unwilling to make long term relationship with company.
\end{abstract}

Keywords: sales person,ethical behavior, loyalty, relationship quality

\section{Pendahuluan}

Para pemasar jasa mengakui bahwa sangatlah penting untuk memelihara hubungan yang berkelanjutan dengan konsumen (Wang et al., 2008). Hal ini sangat tepat dalam konteks jasa yang ditandai dengan aktivitas pertukaran yang terusmenerus dan sifat pembeliannya dianggap tidak pasti. Untuk jasa-jasa tertentu seperti perbankan, untuk memaksimalkan kinerja jangka panjangnya seperti retensi pelanggan dan loyalitas pelanggan, harus membangun, mempertahankan dan méningkatkan hubungan yang saling menguntungkan dengan pelanggan sasaran (Alrubaiee dan Alnazer, 2010).

Ketika membahas strategi hubungan dengan pelanggan, etika bisnis ménjadi topik yang sangat signifikan untuk dibahas (Nill dan Schibrowsky, 2007) dan salah satu elemen penting dalam perusahaan yang sangat erat hubungannya dengan etika adalah kinerja tenaga penjual (Hansen dan Riggle, 2009). Perilaku etis tenaga penjual dapat memainkan peran penting dalam memelihara hubungan jangka panjang dengan konsumen (Chen dan Mau, 2009 dalam Alrubaiee, 2012). Hal ini penting dalam jasa karena seringkali konsumen dihadapkan pada credence quality, yaitu kualitas yang tidak mudah dievalusasi meskipun setelah membeli

- Dosen Fakultas Ekonomi Universitas Islam Agung Semarang 
(Tjiptono, 2005), sehingga konsumen mencari-cari petunjuk yang dapat digunakannya untuk mengevaluasi jasa tersebut. Salah satu petunjuk yang dapat digunakan pelanggan untuk mengevaluasi jasa adalah kinerja karyawan termasuk perilaku etisnya. Hansen dan Riggle (1999) mengatakan bahwa karyawan (tenaga penjual) yang berperilaku etis sangat efektif untuk membangun hubungan yang kuat dengan konsumen, selanjutnya konsumen akan merasa puas, lebih percaya dan atau komit dengan mereka (Hansen dan Riggle, 2009; Walter et al., 1999). Meskipun telah banyak yang mengakui peran etika tenaga penjual dalam memainkan peran penting dalam proses membangun hubungan, namun bukti empiris tentang hal ini masih sangat terbatas (Hansen dan Riggle, 2009). Artikel ini mencoba untuk menggali studi tentang peran perilaku etis tenaga penjual untuk menciptakan kepercayaan, komitmen dan loyalitas pelanggan.

\section{Perilaku Etis Tenaga Penjual}

Menurut Roman dan Ruiz (2005), perilaku etis dalam konteks hubungan penjualan menunjukkan perilaku tenaga penjual yang menawarkan kesejahteraan bagi konsumen. Selanjutnya Roman dan Ruiz (2005) mendefinisikan perilaku etis tenaga penjual sebagai perilaku jujur dan adil tenaga penjual yang memungkinkan mereka untuk ikut meningkatkan hubungan jangka panjang dengan konsumen berdasarkan pada kepuasan dan kepercayaan. Ciri khusus dari perilaku seorang tenaga penjual adalah melakukan interaksi dengan konsumen dan perilaku mereka nampak jelas, sehingga perilaku yang tidak etis sangat besar mempengaruhi opini publik (Mantel, 2005). Definisi perilaku etis dan perilaku tidak etis didasarkan pada persepsi penilaian benar dan salah, baik dan buruk, adil dan tidak adil, pantas dan tidak pantas (Roman, 2003). Perilaku etis tenaga penjual merupakan konstruk yang sukar dipahami dan bersifat spesifik (Lagace et al., 1991). Seorang tenaga penjual biasanya melakukan perilaku tidak etis karena tujuan jangka pendek, mereka hanya berpikit tentang target, sehingga untuk menutupi hal itu perilaku etis seringkali dilakukan. Beberapa contoh perilaku tidak etis dari seorang tenaga penjual adalah: berdusta atau membesar-besarkan tentang manfaat produk, ketersediaan produk, persaingan, menjual produk yang tidak dibutuhkan konsumen, memberikan jawaban yang tidak benar-benar diketahui dan menerapkan taktik mempengaruhi yang memanipulasi/menerapkan teknik penjualan yang menekan (Cooper dan Frank, 2002). Seorang tenaga penjual yang berperilaku tidak etis mempunyai pengaruh negatif terhadap kepuasan dan retensi pelanggan. Dubinsky et al. (1992) berpendapat bahwa perilaku tidak etis dari tenaga penjual akan menyebabkan ketidakpuasan pelanggan, rekomendasi dari mulut le mulut yang negatif, kehilangan pelanggan, menurunkankan penjualan, dan laba (Burnett et al., 2008). 
Untuk mengukur perilaku etis tenaga penjual, dalam penelitiannya pada industri perbankan, Alrubaiee (2012) menggunakan item-item pernyataan: 1) tenaga penjulan di bank ini berbohong tentang ketersediaan produk hanya untuk mịngejar target penjualan, 2) tenaga penjualan berbohong akan kondisì persaingan hanya untuk mengejar target penjualan, 3) tenaga penjualan bank ini memberikan jawaban meskipun mereka tidak benar-benar tahu tentang jawaban itu, 4) tenaga penjualan bank ini memaksa saya untuk mengambil suatu produk meskipun dia tahu bahwa produk itu tidak saya butuhkan.

\section{Kualitas Hubungan}

Kualitas hubungan diartikan sebagai sebuah paket nilai intangible yang menambah manfaat produk dan menghasilkan harapan dari sebuah pertukaran antara penjual dan pembeli (Levitt, 1986). Kualitas hubungan pemasaran dapat dianggap sebagai penilaian menyeluruh dari sebuah hubungan (De Wulf et al., 2001). Henning-Thurau dan Klee (1997) menyatakan bahwa kualitas hubungan dapat dilihat sebagai tingkat kelayakan dari sebuah hubungan untuk memenuhi kebutuhan konsumen berkenaan dengan suatu hubungan.

Banyak riset yang telah menunjukkan bahwa banyak manfaat yang dapat diambil dari sebuah hubungan pemasaran, termasuk meningkatkan keunggulan kompetitif dan meningkatkan kepuasan pelanggan. Amett dan Badrinayaranan (2005) dalam studinya menyarankan sejumlah faktor yang mempengaruhi kesuksesan hubungan pemasaran, tiga faktor penting diantaranya adalah kepercayaan, komitmen dan komunikasi. Morgan dan Hunt (1994) menyatakan bahwa kepercayaan dan komitmen secara simultan dapat memprediksi kinerja pertukaran, sementara yang lain menyatakan bahwa kepercayaan dan komitmen secara parsial merupakan konstruk hubungan yang penting (Palmatier et al., 2006). De Wulf et al. (2006) menyatakan bahwa konstruk kualitas hubungan direfleksikan oleh kombinasi antara komitmen, kepercayaan dan kepuasan terhadap suatu hubungan.

\section{Kepercayaan}

Dalam membina suatu hubungan tentu diperlukan suatu sikap percaya kepada partner kerja. Sirdeshmukh et al. (2002) menyatakan bahwa kepercayaan sebagai harapan konsumen bahwa penyedia jasa dapat dipercaya dalam memenuhi janji-janjinya. Hall (2005) menjelaskan bahwa seseorang yang percaya mempunyai harapan bahwa orang yang dipercaya akan berperilaku baik terhadap mereka. Morgan dan Hunt (1994) mendeskripsikan kepercayaan sebagai komponen sentral dalam pertukaran relasional (Crosby et al., 1990). Speekman (1988) menyatakan bahwa kepercayaan merupakan konstrak hubungan yang merupakan pijakan awal 
dalam strategi parthnership. Mishra et al. (2008) menyebutkan bahwa terdapat tiga dimensi yang membentuk kepercayaan, yaitu: keahlian, dapat dipercaya dan perhatian. Garbarino dan Johnson (1999) mengemukakan bahwa bagi pelanggan tetap, rasa percaya merupakan perantara utama dalam mempengaruhi niat berperilaku dibandingkan dengan kepuasan keseluruhan.

Kumar et al. (1995) mengemukakan bahwa kepercayaan meliputi dua unsur, yaitu kejujuran (honesty) dan kebaikan hati (benevolence). Kepercayaan pada kejujuran mitra kerja mengarah pada keyakinan bahwa mitra kerja tersebut menepati kewajiban yang dijanjikan dan jujur. Kepercayaan pada kebaikan hati menunjuk pada suatu keyakinan bahwa mitra kerja memperhatikan kesejahteraan partner lain dan selalu memotivasi serta mengajak bekerjasama. Konsep tersebut dipertegas oleh Doney dan Cannon (1997) yang mengatakan bahwa konsep kepercayaan ini cocok dalam konteks perusahaan yang bergerak dalam bidang penjualan atau distribusi.

Parsons (2002) menyatakan bahwa keterbukaan sangat penting dalam mewrjudkan kepercayaan. Dalam konteks hubungan bisnis antara perusahaan dengan pengecer, keterbukaan ini dapat muncul dalam bentuk pertukaran informasi. Indikator untuk mengukur variabel kepercayaan dapat disarikan dari pendapat Kumar (1995), Ganesan (1994), Doney dan Cannon (1997), yaitu: rasa percaya terhadap kewajiban-kewajiban yang dijanjikan perusahaan, rasa percaya terhadap komitmen perusahaan dan rasa percaya terhadap kepedulian perusahaan untuk meningkatkan kesejahteraan.

Untuk mengukur variabel kepercayaan, dalam penelitiannya di industri perbankan, Alrubaiee (2012) menggunakan item-item pernyataan: 1) saya merasa bank ini dapat dipercaya, 2) saya percaya akan produk dan jasa bank ini, 3) saya percaya akan informasi-informasi yang diberikan bank ini, 4) secara umum saya tidak punya rasa khawatir sama sekali dalam bekerjasama dengan bank ini, 5) bank ini jujur dan berkata apa adanya, 6) bank ini dapat dipercaya dalam hal memenuhi janji-janjinya.

\section{Komitmen}

Dalam literatur hubungan pemasaran, konsep komitmen memainkan peran penting dan menjadi ciri umum dari model hubungan pemasaran (Alrubaiee dan Alnazer, 2010). Relasi dibangun atas dasar saling komitmen satu pihak dengan pihak yang lain (Morgan dan Hunt, 1994). Riset membuktikan bahwa komitmen sebagai inti kesuksesan hubungan kerja dan sangat penting bagi kesuksesan hubungan jangka panjang (Anderson dan Narus, 1990). Komitmen menciptakan kondisi tertentu yang kemudian akan mendorong tindakan untuk memastikan kelanjutan hubungan sehingga komitmen berorientasi pada pembentukan hubungan jangka panjang (Heidi, 1994). Komitmen mengacu pada janji ekplisit maupun 
implisit dari keberlangsungan hubungan antara pihak-pihak yang mengadakan pertukaran (Morgan dan Hunt, 1994) dan komitmen ini menunjukkan puncak dari ikatan suatu hubungan (Dwyer et al., 1987). Untuk mengukur komitmen, Kim dan Frazier (1997) menggunakan indikator-indikator: keinginan untuk melanjutkan hubungan, kesediaan untuk membuat pengorbanan-pengorbanan jangka pendek, percaya akan stabilitas hubungan, dan bersedia berinvestasi dalam suatu hubungan.

Untuk mengukur variabel komitmen ini, dalam penelitiannya di industri perbankan, Alrubaiee (2012) menggunakan item-item pernyataan: 1) saya ingin tetap menjadi nasabah bank ini karena saya merasa senang berhubungan dengan bank ini, 2) saya memiliki loyalitas yang kuat terhadap bank ini, 3) saya merasa memiliki bank ini, 4) saya sangat berkomitmen untuk menjalin hubungan dengan bank ini, 5) hubungan saya dengan bank ini sangat penting, 6) hubungan saya dengan bank ini adalah sesuatu yang akan saya jaga dalam waktu yang tak terbatas.

\section{Loyalitas Pelanggan}

Menurut Hanning-Thurau, Langer dan Hansen (2001) loyalitas pelanggan secara luas diterima sebagai sesuatu yang membantu perusahaan untuk mencapai kesuksesan jangka panjang, oleh karena itu dalam konteks pemasaran, loyalitas pelanggan merupakan harapan utama yang ingin dicapai perusahaan. Dalam konteks pemasaran, konsep loyalitas merupakan kajian yang sangat penting.

Auh (2005) mengatakan bahwa loyalitas dapat berupa kesediaan untuk melakukan pembelian ulang dan tetap bersedia melakukan pembelian ulang meskipun dengan adanya kenaikan harga. Menurut Palmatier et al. (2006) loyalitas merupakan hasil dari kombinasi atau hubungan multidimensi dari minat, sikap, prestasi penjualan dan perilaku pelanggan. Zeithaml (2000) menjelaskan bahwa pelanggan yang loyal biasanya melakukan beberapa hal berikut ini: (1) Secara terus menerus melakuka komunikasi dari mulut ke mulut, (2) Tidak mempunyai keinginan untuk berpindah ke pesaing (3) Membeli lebih banyak produk dari perusahaan.

i American Marketing Association (2007) mendefinisikan loyalitas sebagai tingkat dimana seorang konsumen secara konsisten terpola dengan toko yang sama ketika berbelanja produk-produk yang biasa dibeli. Definisi tentang loyalitas pelanggan dapat diperoleh dari beberapa sumber. Oliver (1997) mendefinisikan loyalitas pelanggan sebagai komitmen yang mendalam untuk membeli kembali di kemudian hari, meskipun pengaruh situasional dan upaya-upaya pemasaran memiliki potensi untuk menyebabkan perilaku berpindah.

Menurut Fedwick (dalam Sasana, 2005) loyalitas terbagi menjadi empat golongan yaitu konsumen loyal (entreched), konsumen normal (average) konsumen setengah loyal (shallow) dan konsumen tidak loyal (convertible). Konsumen loyal adalah konsumen yang tidak akan pindah ke produk yang lain atau 
merk lain, sedangkan konsumen normal adalah konsumen yang masih mempunyai loyalitas yang tinggi, tetapi masih ada kemungkinan pindah ke produk lain atau merek lain. Tingkat konsumen yang ketiga adalah konsumen setengah loyal yang artinya konsumen masih mempunyai sikap loyal terhadap merek tertentu, namun sebagian sikapnya adalah sikap swicther. Tingkat konsumen yang tidak loyal adalah, konsumen yang akan selalu dari satu merk atau produk ke merek atau produk lainnya.

Setiap ahli mempunyai pendapat masing-masing mengenai tingkatan loyalitas. Menurut Mowen dan Minor (2002), kesetiaan konsumen dapat didefinisikan dari sikap positif yang ditunjukan oleh konsumen terhadap merek atau produk atau jasa tertentu, dan berniat melakukan pembelian secara berulang terhadap produk atau jasa dengan merek tertentu. Semakin tingginya loyalitas yang ditunjukan oleh konsumen, maka semakin besar pula keuntungan yang didapatkan oleh perusahaan tertentu, oleh sebab itu perusahaan harus dapat mengetahui sejauh mana loyalitas konsumen terhadap produk yang dihasilkan.

Menurut Assael (1995), loyalitas konsumen atau kesetiaan merek merupakan sikap terhadap suatu merek tertentu yang ditunjukan dengan sikap pembelian secara berulang-ulang atau terus menerus terhadap merek tersebut. Konsumen yang menunjukkan sikap membeli merek yang sama secara berulangulang kali menandakan konsumen tersebut mempunyai sikap yang loyal.

Menurut Aaker (1997) pengukuran loyalitas konsumen dapat dibagi menjadi empat yaitu: (1) Repurchase Rate adalah persentase konsumen yang akan membeli produk yang sama pada pembelian berikutnya. Dalam pengukuran ini ada dua macam istilah yang digunakan yaitu, percent of purchase dan number of brand purchase. Percent of purchase adalah persentase produk lain yang dibeli, sedangkan number of brand purchase adalah jumlah produk yang digunakan. Number of brand purchase digunakan pada konsumen yang membeli dan menggunakan satu produk, dua produk atau lebih. (2) Switching cost adalah perbedaan pengorbanan atau risiko biaya gagal, energi dan fisik yang dikeluarkan konsumen karena memilih salah satu alternatif. Switching cost tidak hanya mencakup risiko keuangan saja melainkan, mencakup segala hal yang ditanggung konsumen karena telah memilih berganti produk. (3) Commitment artinya semakin besar komitmen konsumen maka semakin besar juga tingkat loyalitas konsumen, dengan demikian juga pangsa pasar tersebut. (4) Liking of Brand, pada dasarnya terdapat rasa suka atau minat yang besar berbeda dari atribut-atribut spesifik yang mendasarinya. Konsumen bisa saja suka terhadap suatu merek dan rasa tersebut tidak bisa dijelaskan sepenuhnya melalui persepsi dan kepercayaan konsumen mengenai atribut-atribut merek tersebut. Rasa suka tersebut bisa saja dijelaskan melalui pernyataan-pernyataan umum mengenai rasa suka atau suatu merek. 
Guna mengukur loyalitas pelanggan, dalam penelitiannya di jasa perbankan, Alrubaiee (2012) menggunakan item-item pertanyaan: 1) saya bersedia menempatkan bisnis masa depan saya bersama bank ini, 2) bank ini merupakan pilihan pertama saya ketika saya ingin berlangganan kembali dengan suatu bank. 3) saýa akan merekomendasikan bank ini ke teman-teman dan keluarga saya, 4) saya. akan memperkenalkan bank ini dengan evaluasi yang positif, 5) saya merasa puas mengadakan kontrak dengan bank ini, 6) saya bersedia mendorong orang lain untuk berbisnis dengan bank ini.

\section{Hubungan antar Variabel}

Para ahli menyimpulkan bahwa upaya hubungan pemasaran yang sukses seperti kualitas hubungan, meningkatkan loyalitas pelanggan dan kinerja perusahaan dapat dicapai melalui ikatan hubungan yang kuat (Alrubaiee dan Alnazer, 2010). Kepercayaan dan komitmen biasanya secara bersama-sama digunakan untuk menguji hubungan pemasaran (Alrubaiee, 2012).

Banyak peneliti menganggap bahwa kepercayaan sebagai anteseden bersama-sama dengan komitmen dan hubungan yang sukses (Cater dan Zabkar, 2008 dalam Alrubaiee, 2012). Namun, bagaimanapun juga, kepercayaan merupakan ukuran perilaku yang menonjol dari komitmen (Coote et al., 2003). Artinya kepercayaan mempunyai pengaruh positif terhadap komitmen. Kepercayaan mengurangi persepsi risiko sehingga mengarahkan pada komitmen yang tinggi untuk melakukan suatu hubungan Morgan dan Hunt (1994)

Pengaruh kepercayaan terhadap komitmen terjadi dalam tiga cara yaitu: 1) kepercayaan mengurangi pandangan tentang risiko yang mungkin timbul karena tindakan oportunis, 2) kepercayaan memberikan keyakinan bahwa kerugian jangka pendek akan lunas dalam jangka panjang dan, 3) kepercayaan akan mengurangi biaya transaksi dalam hubungan bisnis (Ganesan, 1994).

Kepercayaan merupakan faktor penentu yang signifikan atas komitmen untuk melakukan hubungan (Morgan dan Hunt, 1994). Semakin besar kepercayaan maka akan semakin besar keinginan untuk melakukan komitmen hubungan jangka panjjang (Gundlach dan Mentzer, 1995 dalam Alrubaiee, 2012): Hal yang sama dikatakan oleh Singh dan Sirdeshmukh (2000) yang mengatakan bahwa peran kepercayaan sebagai perekat yang mengarah pada hubungan jangka panjang. Cater dan Zabkar (2008) menyatakan bahwa dalam suatu hubungan, jika semakin kepercayaan semakin tinggi, maka kemungkinan besar pelanggan akan bersedia melanjutkan hubungan, mereka menyukai penyedia jasa dan senang bekerje dengan mereka. Alrubaiee dan Alnazer (2010) menemukan bukti awal dari hubungan pemasaran terhadap loyalitas nasabah bank. Holden (1990) dalam Alrubaiee (2012) membuktikan bahwa perilaku etis tenaga penjual berhubungan positif terhadap 
kepercayaan konsumen. Hasil penelitiannya Chen dan Mau (2009) menemukan bahwa perilaku etis tenaga penjualam memainkan peran penting dalam mempengaruhi kepercayaan konsumen. Jadi dapat disimpulkan bahwa, kepercayaan memediasi antara perilaku etis tenaga penjual dengan loyalitas pelanggan. Sanzo (2009) menyatakan bahwa kepercayaan dan komitmen berpengaruh langsung terhadap loyalitas supplier. Wray et al. (1994) menyatakan bahwa etika praktek penjualan, seperti yang dipersepsikan oleh konsumen jasa finansial, meningkatkan kepercayaan terhadap tenaga penjual. Demikian pula hasil studi yang berbeda memperlihatkan bahwa kepercayaan konsumen terhadap tenaga penjual dihasilkan dari kejujuran tenaga penjual (Beatty et al., 1996) dan menerapkan teknik penjualan yang tidak menekan (Kennedy et al., 2001). Konsisten dengan temuan sebelumnya, Roman (2003) telah meneliti tentang konsekuensi dariperilaku etis tenaga penjual: Studi tersebut mengindikasikan bahwa perilaku ini mempeunyai pengaruh positif terhadap kepuasan pelanggan terhadap jasa inti, kepercayaan dan loyalitas. Selanjutnya, Hansen dan Riggle (2009) mengindikasikan bahwa hubungan antara perilaku etis tenaga penjual dan komutmen pembeli melalui tenaga penjual itu dimediasi oleh kepercayaan pembeli pada tenaga penjual. Mereke menyatakan bahwa pengaruh perilaku etis tenaga penjual dengan komitmen pembeli terhadap tenaga penjual hanya muncul ketika pembeli percaya kepada tenaga penjual.

Untuk memperjelas penjelasan sebelumnya, berikut ini diberikan skema yang menjelaskan hubungan variabel:

\section{Gambar 1}

Hubungan Antar Variabel

Kualitas Hubungan

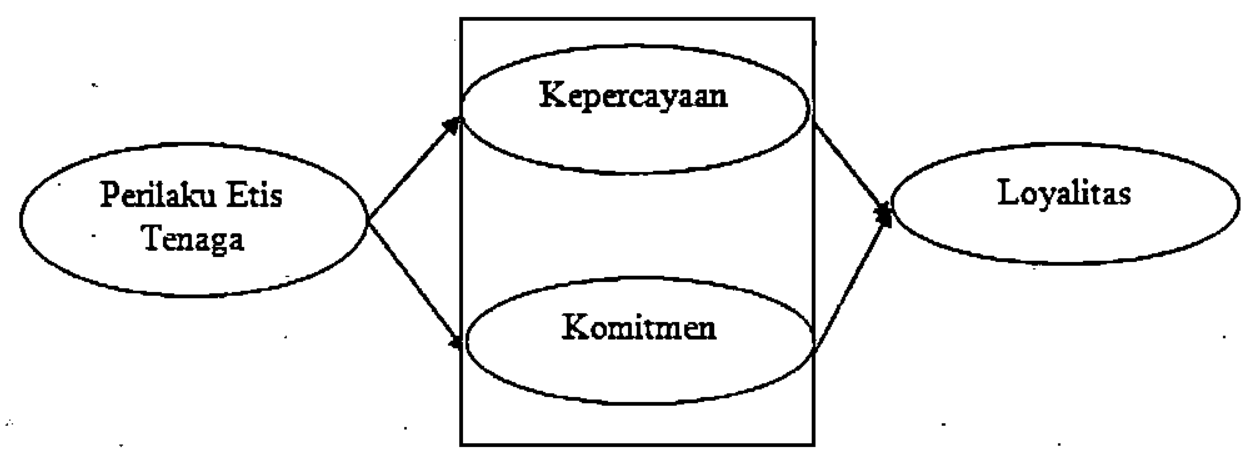




\section{Penutup}

Untuk menciptakan loyalitas pelanggan, perusahaan yang menggunakan tenaga penjual sebagai ujung tombak dalam melayani pelanggan (contohnya: perbankan) harus memperhatikan perilaku etis dari para tenaga penjualannya. Periaku etis tenaga penjual merupakan determinan utama loyalitas pelanggan. Jika tenaga penjualan berperilku etis dengan tidak memaksa konsumen untuk membeli, berkata jujur, memahami dan menguasai product knowlegdenya, maka konsumen akan percaya dan komit terhadap perusahaan. Kepercayaan dan komitmen tersebut maka pelanggan akan merasa senang berhubungan dengan perusahaan dan bersedia melakukan hubungan jangka panjang.

Budaya etis perlu dimunculkan dalam perusahaan dengan jalan menciptakan, memonitor, dan melaksanakan aturan-aturan. Hal itu merupakan langkah awal yang positif untuk mendorong perilaku etis tenaga penjualan 


\section{DAFTAR PUSTAKA}

Alrubaiee, L., and Alkan, Ida, F. 2011. "The MediatingEffect of Patient Satisfaction inthe Patients' Perceptions of Healthcare Quality-Patient Trust Relationship". International Journal of Marketing Studies. 3(1), 103-127

Alrubaiee, L., and Al-Nazer,N. 2010. "Investigate the Impact of Relationship Marketing Orientation on Customer Loyalty: The Customer's Perspective". International Journal of Marketing Studies. 2(1). 155-174

Anderson, J.C., and Narus, J.A. 1990. "A Model of Distributor Firm and Manufacturing Firm Working Parthnerships". Journal of Marketing. 54.42-58

Auh, S. 2005. "The Effects of Soft and Hard Service Attribute on Loyalty: The Mediating Role of Trust". Journal of Service Marketing.19(2). 81-92.

Arnett, Dennis B., and Badrinarayanan. 2005. "Enhancing Customer-Needs-Driven CRM Strategies: Core Selling Teams, Knowledge Management Competence, and Relationship Marketing Competence". Journal of Personal Selling\&Sales Management. 25(4). 329-343

Beatty, S.E., Mayer , M., Coleman, J.E, Reynolds, K.E., and Lee. 1996. "Customer-Sales Associate Retail Relationship". Journal of Retailing. 72(3). 223-247

Burnett, M., Pettijohn, C., and Keith, N. 2008. "A Comparison of the Ethical Perceptions Prospektive Personal Selling and Advertising Employee". The Marketing Management Journal. 18(1). 77-83.

Cooper, R.W. and Frank, G.L. 2002. "Ethical Challenges in the Two main Segments of the Insurance Industry: Key Considerations in the Evolving Financial Service Marketplace". Journal of Business Ethic. 36(1/2). 5-20

Coote, L.V., Forrest, E.J., and Tam, T.W. 2003. "An Investigation into Commitment in non-Western Industrial Marketing Relationships". Industrial Marketing Management. 32. 595-604

Crosby, L.A., Evans,K.R., and Cowles, D. 1990. "Relationship Quality in Service Selling: An Interpersonal Influence Perspektive. Journal of Marketing. 54(3). 68-81

De Wulf, K., Gaby Oderken-Schroder and Lacobucci, D. 2001. "Investments in Consumer Relationships: A Cross-Country and Criss-Industry Exploration". Journal of Marketing. 65(4). 33-50

Doney, P.M., and Cannon, J.P. 1997. "An Exemination of the Nature of Trust in Buyer-Seller Relationship". Journal of Marketing. 61(2). 35-51

Dwyer, F.R., Schurr, P.H., and Oh, S. 1987. "Buyer-Seller Relationship". Journal of Marketing. 51. 11-27 
Nunung Ghoniyah, Peran Perilaku Etis Tenaga Penjual Dalam Membentuk.......

Ganesan, S. 1994. "Determinants of Long-term Orientation in Buyer-Seller Relationship". Journal of Marketing. 58. 1-19

Garbarino, E., and Johnson, M. 1999. "The Different Roles of Satisfaction, Trust and Commitment in Customer Relationship". Journal of Marketing. 63(2).70-87

Hall, M.A. 2005. "The Important of Trust for Ethics, Law and Public Policy". Cambridge Quarterly of Healthcare Ethics. 14(2)

Hansen, John D., and Riggle, Robert J. 2009. "Ethical Salesperson Behavior in Sales Relationships". Journal of Personal Selling and Sales Management. 29(2). 151-166

Henning-Thurau, Thorsten and Klee, Alexander. 1997. "The Impact of Consumer Satisfaction and Relationship Quality on Customer Retention: A Critical Reassessment and Model Development". Psychology\&Marketing. 14(8). 737-764

Kim,K., and Fraizer, G.L. 1997. "Measurement of Distributor Commitment in Industrial Channels of Distribution". Journal of Business Research. 40(2). 139-154

Kennedy, M.S., Ferrell,L.K. and Leclair, D.T. 2001. "Consumer's Trust of Salesperson and Manufacturer: An Empirical Study". Journal of Business Research.51. 73-86

Liljander, V., and Mattson, J. 2002. "Impact of Customer Pre Consumption Mood on the Evaluation of Employee Behavior in Service Encounters". Psychology and Marketing. 19.837-860

Lagace, R.R., Dahlstrom, R., and Gassenheimer, J.B. 1991. "The Relevance of Ethical Salesperson Behavior on Relationship Quality: The Pharmaccutical Industry". Journal of Personal Selling\&Sales Management. 11. 39-47

Mishra, Karen E., and Li, Cong. 2008. "Relationship Marketing in Fortune 500 U.S. and Chinese Web Sites”. Journal of Relationship Marketing. 7(1). 2943

Morgan, R.M., and Hunt, S.D. 1994. "The Commitment-Trust Theory of Relationship marketing". Journal of Marketing. 58(3). 20-38

Mantel, Susam Powell. 2005. "Choice of Perception: How Effect Influences Chioses among Salespeople". Journal of Personal Selling\&Sales Management. 25(1). 43-55

Nill, Alexander and Schibrowsky, John A. 2007. "'Research on Marketing Ethics: A Systematic Review of the Literature". Journal of Macro Marketing. 27. 256-273

Oliver, R.L. 1997. Satisfaction: A Behavioral Perspective on the Customer. New York: McGraw-Hill, Inc. 
Palmatier, Robert W., Dant, Rajiv P., Grewal, Dhruv and Evans, Kenneth R. 2006. "Factors Influencing the Effectiveness of Relationship Marketing: A Meta Analysis". Journal of Marketing. 70(4). 136-153

Roman, Sergio. 2003. "The Impact of Ethical Sales Behavior on Customer Satisfaction, Trust and Loyalty to the Company: An Empirical Study in the Financial Services Industry". Journal of Marketing Management. 19(9-10). 915-939

Sanzo, M.J., Santos,M.L., Vazquez, L. 2003. "The Role Market Orientation in Business Dynamic Relationships: Testing an Integrator Model". Journal of Marketing Management. 19. 73-107

Sirdesmukh, D., Singh, L., and Sabol, B. 2002. "Consumer Trust, Value and Loyalty in Relational Exchanges". Journal of Marketing. 60(1). 15-37

Tjiptono, Fandy. 2005. Pemasaran Jasa. Penerbit Bayumedia. Jakarta

Wang, C.L., Siu,N., and Barnes, B. 2008. " The Significance of Trust and Renging in the Long-term Orientation of Chinese Business-to-Business Relationship". Industrial Marketing Management.37. 819-824

Wray,B., Palmer, A., and Bejou, D. 1994. "Using Neural Network Analysis to Evaluate Buyer-Seller Relationships". European Journal of Marketing. 28(10). 32-48

Zeithaml, V.A. 2000. "Service Quality, Profitability, and the Economic Worth of Customers: What we Know and What We Need toLearn". Journal of the Academy of Marketing Sience. 28(1). 67-85. 